\title{
Impacts of Food Consumption on Biochemical Markers and Anthropometric Variables of Women With Metabolic Syndrome
}

Kelly Michalichen ( $\sim$ kelly.michalichen@uel.br)

Universidade Estadual de Londrina https://orcid.org/0000-0003-4901-5521

Vinícius Muller Reis Weber

UNICENTRO: Universidade Estadual do Centro-Oeste

Marcos Roberto Queiroga

UNICENTRO: Universidade Estadual do Centro-Oeste

Daniel Zanardini Fernandes

UNICENTRO: Universidade Estadual do Centro-Oeste

\section{Clisia Mara Carreira}

Universidade Estadual de Londrina

\section{Edgar Ramos Vieira}

Florida International University Nicole Wertheim College of Nursing and Health Sciences

\section{Danielle Venturini}

UEL: Universidade Estadual de Londrina

\section{Research Article}

Keywords: Women health, Macronutrients, Nutrition

Posted Date: February 22nd, 2022

DOI: https://doi.org/10.21203/rs.3.rs-1338456/v1

License: (9) This work is licensed under a Creative Commons Attribution 4.0 International License. Read Full License 


\section{Abstract}

Background: Metabolic syndrome (MetS) is a group of diseases characterized by insulin resistance. MetS has a high prevalence among women, and food intake impacts MetS. Also, MetS is related to a high level of inflammation in the individual; however, the impacts of whole diets in biochemical and anthropometrical markers and the effects on MetS need to be elucidated. In this case, the objective of this study was assess the relationship between food intake, biochemical and anthropometrical markers in women with MetS.

Methods: This is a cross-sectional study, in which one hundred and twenty-two women participated in the assessment of biochemical (glycated hemoglobin, glycaemia, insulin, uric acid, total cholesterol, HDL-C, LDL-c, triglycerides, C-reactive protein) and anthropometrical (body mass, height, waist circumference WC) variables. The participants also completed blood pressure and the 24-hour dietary recall assessments. Out of the 122 participants, 44 (36\%, age: $59 \pm 11$ years) had MetS and were included in the analysis.

Results: The consumption of monounsaturated fats had a direct relationship with glycaemia $(b=7.27)$, whereas the consumption of fibers had an inverse relationship with body mass $(b=-0.71)$ and WC $(b=-0.56)$.

Conclusion: The intake of monounsaturated fats and fiber was related to higher blood sugar levels and lower body mass and WC, respectively. These relationships elucidate and highlight the significance and importance of adequate diet in women with MetS.

\section{Introduction}

There is a relationship between visceral adiposity and diabetes mellitus, and both are related to atherosclerosis $(1,2)$. In 1977, the combination of obesity, diabetes mellitus, and other clinical conditions was named metabolic syndrome (MetS) $(3,4)$. Many definitions were proposed highlighting visceral adiposity and insulin resistance causing metabolic abnormalities (5). Different criteria are used to classify MetS (6-9). In 2009, to facilitate the comparison between studies, a group of researchers proposed a common definition considering changes in fast glycaemia, hypertension, hypertriglyceridemia, low high-density lipoprotein, or the use of drugs to control any of these factors, and the presence of visceral obesity (10).

There are different interventions to reduce the risk of MetS (9). Changes in lifestyle and eating habits are important, including controlling caloric intake and the intake of saturated fat, cholesterol, salt, and sugar. Increased consumption of fruits, vegetables, and whole grains are also recommended (11). The risk of developing MetS is significantly affected by inadequate food consumption. In addition to food choices, food consumption patterns are also important. Identifying a diet that the individual with MetS is able to 
adhere to, with moderate consumption of macronutrients, is critical $(11,12)$. Carbohydrate consumption influences glycaemia, lipidic profile, inflammatory markers, and insulin resistance $(13,14)$. Metabolic markers are used for clinical decisions; they provide essential information for preventing, diagnosing, treating diseases $(15,16)$. To prescribe or guide an individualized diet it is necessary to consider the metabolic markers for a better prescription. Anthropometric measurements and food consumption patterns are also important to manage health, eating, and nutritional conditions (17).

MetS increases systemic inflammation. The inflammation induced by MetS differs from others processes of inflammation because it involves the immunological system and impacts metabolic homeostasis. These impacts increase inflammatory markers, reduce daily energetic expenditure, promote disfunction in $\beta$ cells from the pancreas, and increase hepatic and cardiovascular diseases $(18,19)$.

The influence of dietary habits on the control or prevention of many diseases is well known. However, more information is needed to elucidate the role of nutritional habits on inflammatory markers in people with MetS $(9,11)$. Moreover, there is a gap in the literature related to the impact of dietary components on different biochemical markers in individuals with MetS (20). Furthermore, there is still a need for information regarding the impact of diets on the components of MetS (21). Considering the scarcity of studies in this are, this study will provide knowledge regarding the potential effects of dietary habits in MetS and promote evidence-based practice. Therefore, this study aimed to assess the relationship between dietary components, biochemical markers, and anthropometric variables in women with MetS. The hypothesis was that adequate dietary intake would be associated with a better biochemical profile and anthropometric markers.

\section{Methods}

\section{Participants}

This was a cross-sectional study of women attending the Multiprofessional Outpatient Women's Health Clinic at the University Hospital. One hundred twenty-two patients were invited to participate during the years of 2018 and 2019. The patients received information about the study's objectives and procedures and signed an informed consent form. The local ethics committee approved the research (protocol \# $2,837,313)$.

The participants completed a questionnaire (personal and clinical information) and anthropometric measurements, reported their 24-h dietary intake, and provided blood samples for biochemical analyses. The inclusion criteria were having metabolic syndrome (MetS) based on the assessment, and the exclusion criteria were having other acute or chronic diseases, renal impairment, neurological diseases or cancer, pregnancy or lactation. The diagnosis of MetS was based on three or more of the following characteristics: i) waist circumference (WC) $\geq 88 \mathrm{~cm}$; ii) $\mathrm{HDL}<50 \mathrm{mg} / \mathrm{dL}$ or using antilipemic; iii) TG $\geq$ $150 \mathrm{mg} / \mathrm{dl}$ or using medication for dyslipidemia; iv) systolic blood pressure (BP) $\geq 130$ and diastolic $\geq$ $85 \mathrm{~mm} / \mathrm{Hg}$ or using antihypertensive drugs; v) Fasting venous glycaemia (FVG) $\geq 100 \mathrm{mg} / \mathrm{dl}$ or using a 
hypoglycemic medication (10). Of the 122 women evaluated, $44(36 \%)$ had MetS and were included in the analyses. The high prevalence of MetS may be explained by the fact that the participants were recruited from a clinical setting where they were receiving care for different health issues, including MetS and its complications.

\section{Anthropometry}

Body mass was measured with the subject standing barefoot and wearing light clothes using a calibrated scale with $0.1 \mathrm{~kg}$ precision. Height was measured using a stadiometer with an accuracy of $0.1 \mathrm{~cm}$. The participants stood barefoot, with their feet together, with eyes gazing at the horizon without tilting or extending the head. BMI was calculated and was adopted the classification of the WHO reference standard [BMI: (weight/height ${ }^{2}$ )] (22) for adult women and Lipschitz (23) for women aged 60 years or over. WC was measured at the midpoint between the costal arch and the iliac crest using an inextensible metric tape (24).

\section{Biochemical analysis}

Blood samples were collected after 12 hours of fasting in tubes without anticoagulant (to obtain serum) with separating gel; one tube containing sodium fluoride for blood glucose determination, and two tubes containing EDTA as anticoagulant and preservative. The plasma and serum were aliquoted and stored in a freezer at $-80^{\circ} \mathrm{C}$ (Indrel $\circledast$ ) until the tests were carried out.

The determination of serum levels of C-reactive protein (CRP) was performed by nephelometry (DadeBehring), ELISA methodology using commercial kits with up to $5.00 \mathrm{mg} / \mathrm{L}$ of a reference value. The analyzes of total cholesterol (CT), HDL cholesterol, Triglycerides (TG), uric acid, glucose, and glycated hemoglobin ( $\mathrm{HbA} 1 \mathrm{c}$ ) were performed in a biochemical autoanalyzer (Dimension-Siemens $\left.{ }^{\circledR}\right)$, using Siemens kits. LDL-c was calculated using the following formula (25):

$L D L-c=$ Cholesterol $-H D L-c-($ Triglycerides $/ 5)$.

Fasting insulin levels were determined by microparticle immunoassay enzyme on the AXSYN equipment (ABBOTT).

The estimation of insulin resistance and beta-cell function was performed from the calculations of the HOMA-IR index (26).

HOMA-IR = fasting blood glucose $(\mathrm{mmol} / \mathrm{L}) \times$ fasting insulinemia $(\mathrm{mU} / \mathrm{L}) / 22.5$

The cut-off points for laboratory tests were in accordance with those already established, with the respective values for each test being considered acceptable. CRP $(\leq 5 \mathrm{mg} / \mathrm{dL}), \mathrm{CT}(<200 \mathrm{mg} / \mathrm{dL}), \mathrm{HDL}$ ( $>50 \mathrm{mg} / \mathrm{dL}), \mathrm{LDL}(<130 \mathrm{mg} / \mathrm{dL}), \mathrm{TG}(<150 \mathrm{mg} / \mathrm{dL})$, urid acid $(\geq 2,6-\leq 6 \mathrm{mg} / \mathrm{dL})$, glucose $(\leq 70-<100$ $\mathrm{mg} / \mathrm{dL}), \mathrm{HbA} 1 \mathrm{c}(\leq 4,8-\leq 6 \%)$, insulin $(\leq 2,7-\leq 10,4 \mu \mathrm{U} / \mathrm{mL})$ e HOMA-IR $(<2,5 \%)$.

\section{Dietary intake assessment}


Dietary intake was determined using a 24-hour recall (27) with the aid of the Dietbox® software to define and quantify all the food and beverages consumed in the 24-hour period before the interview (28). The 24-hour recall has good reproducibility with correlation coefficients between 0.36 to 0.69 and the weighted Kappa over 0.4. The validity has correlation coefficients between 0.21 and 0.74 (29).

Information on dietary intake was obtained regarding the consumption of proteins, carbohydrates, sugars, fibers, total fats, polyunsaturated fats, monounsaturated, saturated, trans, cholesterol, fibers, and micronutrients. The researcher encouraged the women to remember the food intake with a detailed description of the foods and amounts during the interview. The researcher also revised the information at the end of the interview.

To characterize the food intake as adequate or not, the total intake of macronutrients follows the recommendations of the Update of the Brazilian Guideline on Dyslipidemia and Atherosclerosis Prevention of the Brazilian Society of Cardiology (30).

\section{Statistical Analysis}

Sample characteristics were presented as means and standard deviations (SD). The Shapiro-Wilk test was used to verify data normality. Food consumption was presented by total amounts or daily percentages. The associations between food consumption, anthropometrical and biochemical variables were assessed using multiple linear regression controlled by medications (hypoglycemic, hypolipemic, and insulin or similar) and age. The regressions were expressed as regression coefficients $(\beta)$ and standard errors (SE). Residual analyses were performed to verify the regression's adequacy. A significance of $5 \%$ was adopted, and the data were analyzed using SPSS software version 25.0.

\section{Results}

Medications were used by $98 \%$ of the participants $(n=43)$ to manage MetS. A total of $61 \%(n=27)$ used oral hypoglycemic agents, and $32 \%(n=14)$ used insulins and analogues. Age and anthropometrical, biochemical, and nutritional markers are shown in the Table 1. Blood pressure was within normal levels for MetS patients. As for body composition, 43\% $(n=19)$ were overweight and $53 \%(n=23)$ were obese. 
Table 1

- Age, Biochemical markers, anthropometric values, and dietary intake of women with metabolic syndrome.

\begin{tabular}{|c|c|c|c|}
\hline \multirow[t]{2}{*}{ Variables } & \multirow[t]{2}{*}{ Mean \pm SD } & \multicolumn{2}{|c|}{ Adequate } \\
\hline & & $\%$ & $\mathbf{n}$ \\
\hline Age (years) & $59.0 \pm 10.8$ & & \\
\hline \multicolumn{4}{|l|}{ Anthropometric } \\
\hline Body mass (kg) & $83.3 \pm 12.7$ & & \\
\hline Heigh (cm) & $155.9 \pm 5.4$ & & \\
\hline BMI $\left(\mathrm{kg} / \mathrm{m}^{2}\right)$ & $34 \pm 5$ & 3 & 2 \\
\hline Waist Circumference (cm) & $109 \pm 13$ & 2 & 1 \\
\hline \multicolumn{4}{|l|}{ Biochemical markers } \\
\hline HbA1c (\%) & $7 \pm 1$ & 36 & 16 \\
\hline Glycaemia (mg/dL) & $133 \pm 57$ & 27 & 12 \\
\hline Insulin $(\mu \mathrm{U} / \mathrm{mL})$ & $16 \pm 9$ & 25 & 11 \\
\hline Homa - Rl index & $5 \pm 4$ & 23 & 10 \\
\hline Uric acid (mg/dL) & $5 \pm 1$ & 71 & 31 \\
\hline Total cholesterol (mg/dL) & $188 \pm 40$ & 66 & 29 \\
\hline HDL-c (mg/dL) & $45 \pm 9$ & 27 & 12 \\
\hline LDL-c (mg/dL) & $112 \pm 35$ & 71 & 31 \\
\hline TGL-c (mg/dL) & $179 \pm 89$ & 46 & 20 \\
\hline C-reactive protein $(\mathrm{CRP})(\mathrm{mg} / \mathrm{L})$ & $6 \pm 5$ & 59 & 26 \\
\hline \multicolumn{4}{|l|}{ Dietary intake } \\
\hline Energy (kcal/day) & $1354 \pm 485$ & 16 & 7 \\
\hline Protein (g/day) & $59 \pm 30$ & 34 & 15 \\
\hline Carbohydrate (g/day) & $168 \pm 60$ & 34 & 15 \\
\hline Total fat (g/day) & $52 \pm 28$ & 39 & 17 \\
\hline Saturated fat (g/day) & $17 \pm 12$ & 18 & 8 \\
\hline \multicolumn{4}{|c|}{$\begin{array}{l}\text { The energetic adequation follow the recommendation of DRI's (59). Adequate: Values in accordance } \\
\text { to describe in methods for each category. BMI: body mass index; HbA1c: glycated hemoglobin; Homa } \\
\text { (IR): Homeostatic Model Assessment - Insulin resistance; HDL-c: High-density lipoprotein; LDL-C: } \\
\text { Low-density lipoprotein; TGL: Triglycerides. Values expressed as mean and standard deviation }\end{array}$} \\
\hline
\end{tabular}




\begin{tabular}{|llll|}
\hline Variables & Mean \pm SD & \multicolumn{2}{c|}{ Adequate } \\
\cline { 3 - 4 } & & $\%$ & $\mathbf{n}$ \\
\hline Trans fat (g/day) & $1 \pm 1$ & 27 & 12 \\
\hline Polyunsaturated fat(g/dia) & $12 \pm 5$ & 48 & 21 \\
\hline Monounsaturated fat (g/day) & $16 \pm 11$ & 7 & 3 \\
\hline Fiber (g/day) & $13 \pm 6$ & 41 \\
\hline $\begin{array}{l}\text { The energetic adequation follow the recommendation of DRI's (59). Adequate: Values in accordance } \\
\text { to describe in methods for each category. BMl: body mass index; Hb1c: glycated hemoglobin; Homa } \\
\text { (IR): Homeostatic Model Assessment - Insulin resistance; HDL-C: High-density lipoprotein; LDL-c: } \\
\text { Low-density lipoprotein; TGL: Triglycerides. Values expressed as mean and standard deviation }\end{array}$ \\
\hline
\end{tabular}

Regarding food consumption, $82 \%(n=36), 52 \%(n=23)$ and $59 \%(n=26)$ presented high/inadequate consumption of saturated, polyunsaturated, and monounsaturated fats, respectively (Table 1); $66 \%(n=$ 29) of women did not consume adequate levels of protein. The consumption of carbohydrates was adequate for only $34 \%(n=29)$ of the participants, and only $7 \%(n=3)$ consumed adequate levels of fibers.

The prevalence (\%) of disorders related to MetS among the participants is shown in Figure 1. WC was high $(>88 \mathrm{~cm})$ in $98 \%(n=43), 91 \%(n=40)$ had low HDL-C or used drug treatment for reduced HDL-C, $84 \%(n=37)$ had hypertension or used antihypertensives, and $86 \%(n=39)$ had high concentration of TG or used medication for dyslipidemia.

Table 2 shows the relationship between food consumption and biochemical variables. The relationship between the consumption of monounsaturated fats and the glycemic values was significant ( $\beta$ : 7.27; $\mathrm{P}<0.05)$. The consumption of other macronutrients, on the other hand, did not show a significant relationship with the biochemical variables. 
Table 2

- Relationship between dietary intake and biochemical markers of women with metabolic syndrome.

\begin{tabular}{|c|c|c|c|c|c|c|c|}
\hline \multirow{3}{*}{ HbA1c } & \multirow{2}{*}{$\begin{array}{l}\text { Kcal } \\
\text { total }\end{array}$} & \multirow[t]{2}{*}{ Protein } & \multirow[t]{2}{*}{ Lipids } & \multirow[t]{2}{*}{$\mathrm{CHO}$} & \multicolumn{2}{|l|}{ Fat } & \multirow[t]{2}{*}{ Fiber } \\
\hline & & & & & Poli & Mono & \\
\hline & 0.001 & 0.001 & -0.05 & -0.001 & 0.02 & 0.11 & 0.01 \\
\hline & $(0.01)$ & $(0.03)$ & $(0.06)$ & $(0.02)$ & $(0.04)$ & $(0.07)$ & $(0.03)$ \\
\hline \multirow[t]{2}{*}{ Glycaemia } & 0.13 & -0.24 & -3.85 & -0.48 & 0.62 & 7.27 & -0.46 \\
\hline & $(0.29)$ & $(1.29)$ & $(2.85)$ & $(1.11)$ & $(2.2)$ & (3.31) & $(1.33)$ \\
\hline \multirow[t]{2}{*}{ Insulin } & 0.002 & 0.041 & -0.063 & 0.02 & 0.5 & 0.14 & 0.07 \\
\hline & $(0.05)$ & $(0.23)$ & $(0.52)$ & $(0.20)$ & $(0.39)$ & $(0.6)$ & $(0.24)$ \\
\hline \multirow[t]{2}{*}{ Homa RI } & -0.001 & 0.02 & -0.10 & 0.01 & 0.16 & 0.3 & -0.02 \\
\hline & $(0.02)$ & $(0.08)$ & $(0.18)$ & $(0.07)$ & $(0.14)$ & $(0.21)$ & $(0.08)$ \\
\hline \multirow[t]{2}{*}{ Uric acid } & 0.003 & 0.01 & 0.001 & -0.01 & -0.07 & -0.09 & 0.05 \\
\hline & $(0.01)$ & $(0.04)$ & $(0.08)$ & $(0.03)$ & $(0.06)$ & $0.1)$ & $(0.04)$ \\
\hline \multirow[t]{2}{*}{ CT } & 0.19 & 1.01 & 1.59 & 0.76 & -1.39 & -1.08 & -1.4 \\
\hline & $(0.23)$ & $(1.02)$ & $(2.27)$ & $(0.88)$ & $(1.72)$ & $(2.63)$ & $(1.06)$ \\
\hline \multirow[t]{2}{*}{ HDL } & -0.03 & 0.08 & 0.31 & 0.14 & 0.09 & -0.21 & -0.24 \\
\hline & $(0.06)$ & $(0.25)$ & $(0.55)$ & $(0.22)$ & $(0.42)$ & $(0.64)$ & $(0.6)$ \\
\hline \multirow[t]{2}{*}{ TGL } & -0.14 & 1.39 & 1.6 & 0.14 & -1.31 & -1.7 & 2.24 \\
\hline & $(0.54)$ & $(2.41)$ & $(5.33)$ & $(2.08)$ & $(4.05)$ & $(6.17)$ & $(2.5)$ \\
\hline \multirow[t]{2}{*}{ CRP } & 0.003 & 0.02 & -0.16 & 0.002 & 0.11 & 0.29 & -0.004 \\
\hline & $(0.03)$ & $(0.12)$ & $(2.63)$ & $(0.10)$ & $(0.2)$ & $(0.31)$ & $(0.1)$ \\
\hline
\end{tabular}

Table 3 shows the relationship between food consumption and anthropometric variables. There was an inverse relationship between fiber consumption and body mass $(\beta$ : $-0.71 ; P<0.05)$ and waist circumference $(\beta$ : $-0.56 ; P<0.05)$. 
Table 3

Relationship between the dietary intake and the anthropometric measurements of women with metabolic syndrome.

\begin{tabular}{|c|c|c|c|c|c|c|c|}
\hline & Kcal total & Protein & Lipids & $\mathrm{CHO}$ & Fat & & Fiber \\
\hline & & & & & Poly & Mono & \\
\hline Body mass $(\mathrm{kg})$ & -0.04 & 0.26 & -0.01 & 0.24 & 0.08 & 0.82 & -0.71 \\
\hline & $(0.06)$ & $(0.3)$ & $(0.61)$ & $(0.26)$ & $(0.50)$ & $(0.78)$ & $(0.32)$ \\
\hline $\mathrm{BMI}\left(\mathrm{kg} / \mathrm{m}^{2}\right)$ & -0.02 & 0.12 & 0.11 & -0.05 & 0.49 & 0.13 & -0.14 \\
\hline & $(0.03)$ & $(0.12)$ & $(0.10)$ & $(0.24)$ & $(0.31)$ & $(0.2)$ & $(0.12)$ \\
\hline WC (cm) & -0.04 & 0.3 & 0.3 & -0.04 & 0.78 & 0.30 & -0.56 \\
\hline & $(0.07)$ & $(0.30)$ & $(0.26)$ & $(0.62)$ & $(0.79)$ & $(0.51)$ & $(0.32)$ \\
\hline
\end{tabular}

The values were expressed in Beta coefficient and standard error (SE). WC: Waist circumference; $\mathrm{CHO}$ : Carbohydrates. Bold letter: $P<0.05$.

\section{Discussion}

This research aimed to assess the relationship between food consumption, biochemical markers, and anthropometric values in women with MetS. There was a significant relationship between the consumption of monounsaturated fat and fast glycaemia, and an inverse relationship between fiber consumption, body mass and waist circumference.

Recent studies emphasize the impact of macronutrient intake on the energetic biomarkers related to metabolic health; genetic effects are more powerful when healthy diets are consumed (31). The interactions gene/macronutrient modulates the risk of obesity and metabolic diseases (32). In the present study, high ingestion of fats and low ingesting of fibers was noted. There was a direct relationship between monounsaturated fat intake and high fast glycaemia. Monounsaturated fat intake was from a high amount of red meat and dairy products; distinct cardiometabolic effects are related to intake of mono or polyunsaturated fats (33). Jiao et al. (34) found a positive association between monounsaturated fat and mortality.

Consumption of red meat, especially processed meat, was related to an increase in diabetes. In contrast, the intake of milk, cheese, and yogurt showed a neutral effect over cardiometabolic effects. Vegetables that provide monounsaturated fat had positive cardiometabolic effects $(33,35,36)$. The 24 -h dietary recalls confirmed the choice of unhealthy sources of monounsaturated fat such as processed meats and cheese, which have a high amount of saturated fat that have postprandial effects, promote the store of fat (lipogenesis), increase inflammatory processes and glycaemia $(37,38)$.

Another important factor for metabolic homeostasis is the intestinal microbiota which is dependent on alimentary residues, as fiber, for its surveillance and metabolism (39). Moreover, the intestinal microbiota 
gives high rates of butryogenesis, exercising epigenetics and immunomodulators effects on other organs of the body (40). This information could help understand the relationship between high ingest of fiber and the reduction in many pathologies, including metabolic diseases (41-45). It is important to highlight the low fiber intake found in the present study ( $13 \mathrm{~g} /$ day), which was $50 \%$ less than the recommended 26 $\mathrm{g} /$ day (30).

The analysis of dietary intake and anthropometrics measurements revealed an inverse relationship between the fiber intake and waist circumference. This result agrees with other studies. Liu et al. (46) evaluated 74.091 nurses over 12 years and observed that the nurses with high fiber intake gain less weight than their counterparts. Furthermore, overweight and obese women have lower intake of fruits and vegetables (47). Dietary fiber intake is inversely related to body mass, BMI and WC (48-50). The consumption of fiber is a critical to promote weight loss in subjects with obesity or overweight $(49,50)$. The most prevalent MetS factor in the present study was high WC $(98 \%>88 \mathrm{~cm})$. Fibers prevent obesity by supporting the intestinal microbiota, decreasing the absorption of nutrients (51), inhibiting appetite $(52,53)$, and regulating homeostasis $(54,55)$.

This study demonstrates that small changes in eating habits, as the decrease in monounsaturated fat intake and an increase in fiber intake, could reduce the risk factors for women with MetS. Once the monounsaturated fat has a relationship with glycaemia, fibers have an inverse relationship with body mass and WC. The data found in the study enhance the importance of dietary fiber intake since it could promote beneficial effects on the anthropometric profile.

The present study has some limitations such as the small sample size, only one dietary intake assessment, and lack of data on physical activity levels. The 24-h dietary recall is subject to errors in the representation of actual dietary intake. However, there is no gold standard method available for researchers to evaluate dietary intake $(56,57)$. Even applied only once, this recall search estimates the absolute intake instead of relative through its open structure (58).

\section{Conclusion}

The intake of monounsaturated fats and fiber were associated to higher blood sugar levels and with lower body mass and waist circumference, respectively. These relationships highlight the importance of dietary intake in MetS management in women.

The present study increases the understanding of the relationship between dietary habits, biochemical and anthropometric markers in women with MetS. The findings indicate that the consumption of fibers is important to the control of visceral obesity in women with MetS. Further longitudinal studies are necessary to evaluate the cause-effect relationship between dietary intake and its effects on physiological and anthropometrical markers in people with MetS.

\section{Abbreviations}


BMI

Body Mass index

BP

systolic blood pressure

CRP

C-reactive protein

CT

total cholesterol

FVG

Fasting venous glycaemia

HbA1c

glycated hemoglobin

HDL-C

high-density lipoprotein

LDL-c

low-density lipoprotein

MetS

Metabolic syndrome

SD

standard deviations

SE

standard errors

TG

Triglycerides

WC

waist circumference

$\beta$

regression coefficients

\section{Declarations}

\section{ETHICS APPROVAL AND CONSENT TO PARTICIPATE}

The local ethics committee Ethics Committee in Research with Human Beings of the State University of Londrina approved the research (protocol \# 2,837,313). The patients received information about the study's objectives and procedures and signed an informed consent form.

CONSENT FOR PUBLICATION

Not applicable. 
The datasets used and analyzed during the current study are available from the corresponding author on reasonable request

\section{COMPETING INTERESTS}

The authors declare that they have no competing interests.

\section{FUNDING}

Not applicable.

\section{AUTHORS' CONTRIBUTIONS}

KM: Conception and Design, methodology, data collection, analysis and interpretation of data, drafting the article, final approval.

VW: Conception and Design, analysis and interpretation of data, drafting the article, final approval.

MQ: Revising it critically, interpretation of data, final approval.

DF: Conception and Design, analysis of data, final approval.

CC: Revising it critically, supervision, final approval.

EV: Revising it critically, interpretation of data, final approval

DV: Conception and Design, methodology, drafting the article, supervision, final approval.

\section{ACKNOWLEDGEMENTS}

Not applicable.

\section{References}

1. Vague J. La differentiation sexually, factor determinant des formes de l'ob sit. Press Med. 1947;30:339-40.

2. Haller H. Epidemiology and associated risk factors of hyperlipoproteinemia. Z Gesamte Inn Med. 1977;32:124-8.

3. Gerald B. P. Relationship between serum sex hormones and glucose, insulin, and lipid abnormalities in men with myocardial infarction. Proc Natl Acad Sci U S A. 1977;74:1729-33.

4. Gerald BP. Sex hormones, risk factors and cardiovacular disease. Am J Med. 1978;65:7-11.

5. Gupta A, Gupta V. Metabolic syndrome: What are the risks for humans ? 2010;4(5):204-12.

6. Alberti KGMM, Zimmet PZ. Definition, Diagnosis and Classification of Diabetes Mellitus and its Complications Part 1 : Diagnosis and Classification of Diabetes Mellitus Provisional Report of a 
WHO Consultation. 1998;539-53.

7. Expert panel on detection evaluation. and treatment of high blood cholesterol in adults. Executive summary of the third report (NCEP) -adult treatment panel III. J Am Med Assoc. 2001;285(19):248697.

8. Alberti KGMM, Zimmet P, Shaw J. Metabolic syndrome-a new world-wide definition. A Consensus Statement from the International Diabetes Federation. Diabet Med [Internet]. 2006 May;23(5):46980. Available from: http://doi.wiley.com/10.1111/j.1464-5491.2006.01858.x.

9. Grundy SM, Cleeman JI, Daniels SR, Donato KA, Eckel RH, Franklin BA, et al. Diagnosis and management of the metabolic syndrome: An American Heart Association/National Heart, Lung, and Blood Institute scientific statement. Circulation. 2005;112(17):2735-52.

10. Alberti KGMM, Eckel RH, Grundy SM, Zimmet PZ, Cleeman JI, Donato KA, et al. Harmonizing the metabolic syndrome: $A$ joint interim statement of the international diabetes federation task force on epidemiology and prevention; National heart, lung, and blood institute; American heart association; World heart federation; International. Circulation. 2009;120(16):1640-5.

11. Timóteo AT. Diet in patients with metabolic syndrome: What is the ideal macronutrient composition? Rev Port Cardiol (English Ed [Internet]. 2018;37(12):1001-6. Available from: http://dx.doi.org/10.1016/j.repce.2017.11.021.

12. Alhassan S, Kim S, Bersamin A, King AC, Gardner CD. Dietary adherence and weight loss success among overweight women: Results from the A to Z weight loss study. Int J Obes. 2008;32(6):98591.

13. Sacks FM, Bray GA, Carey VJ, Smith SR, Ryan DH, Anton SD, et al. Comparison of Weight-Loss Diets with Different Compositions of Fat, Protein, and Carbohydrates. N Engl J Med [Internet]. 2009 Feb 26;360(9):859-73. Available from: http://www.nejm.org/doi/10.1056/NEJMoa0804748.

14. Steckhan N, Hohmann CD, Kessler C, Dobos G, Michalsen A, Cramer H. Effects of different dietary approaches on inflammatory markers in patients with metabolic syndrome: A systematic review and meta-analysis. Nutrition [Internet]. 2016;32(3):338-48. Available from:

http://dx.doi.org/10.1016/j.nut.2015.09.010.

15. Beastall GH. Adding value to laboratory medicine: A professional responsibility. Clin Chem Lab Med. 2013;51(1):221-7.

16. Schmidt RL, Ashwood ER. Laboratory medicine and value-based health care. Am J Clin Pathol. 2015;144(3):357-8.

17. Sperandio N, Priore SE. Inquéritos antropométricos e alimentares na população Brasileira: Importante fonte de dados para o desenvolvimento de pesquisas. Cienc e Saude Coletiva. 2017;22(2):499-508.

18. Galassi A, Reynolds K, He J. Metabolic Syndrome and Risk of Cardiovascular Disease: A MetaAnalysis. Am J Med. 2006;119(10):812-9.

19. Saltiel AR, Olefsky JM. Inflammatory linking obesity and metabolic disease and metabolic disease. J Clin Invest. 2017;127(1):1-4. 
20. Calder PC, Ahluwalia N, Brouns F, Buetler T, Clement K, Cunningham K, et al. Dietary factors and lowgrade inflammation in relation to overweight and obesity. Br J Nutr. 2011;106(SUPPL. 3).

21. Semnani-Azad Z, Khan TA, Blanco Mejia S, De Souza RJ, Leiter LA, Kendall CWC, et al. Association of Major Food Sources of Fructose-Containing Sugars with Incident Metabolic Syndrome: A Systematic Review and Meta-analysis. JAMA Netw Open. 2020;3(7):1-15.

22. World Health Organization. Obesity: preventing and managing the global epidemic of obesity. Rep WHO Consult Obes; 1997.

23. Lipschitz DA. Screening for nutritional status in the elderly. Prim Care. 1994;21(1):55-67.

24. World Health Organization. Obesity: preventing and managing the global epidemic of obesity. Tech Rep Ser 894. 2000.

25. Friedewald WT, Levy RI, Fredrickson DS. Estimation of the concentration of low-density lipoprotein cholesterol in plasma, without use of the preparative ultracentrifuge. 1972;18(6):499-502.

26. Matthews DR, Hosker JP, Rudenski AS, Naylor BA, Treacher DF, Turner RC. Homeostasis model assessment: insulin resistance and $\beta$-cell function from fasting plasma glucose and insulin concentrations in man. Diabetologia. 1985;28(7):412-9.

27. Karvetti RL, Knuts LR. Validity of the 24-hour dietary recall. J Am Diet Assoc [Internet]. 1985 Nov;85(11):1437-42. Available from: http://www.ncbi.nlm.nih.gov/pubmed/4056262.

28. National Institutes of Health. National Cancer Institute. Dietary Assessment Primer, 24-hour Dietary Recall (24HR) at a glance. 2017.

29. Selem SS, de C, de Carvalho, Verly-Junior AM, Carlos E, Teixeira JV, Marchioni JA. DML, et al. Validity and reproducibility of a food frequency questionnaire for adults of São Paulo, Brazil. Rev Bras Epidemiol. 2014;17(4):852-9.

30. Arquivos da Sociedade Brasileira de Cardiologia. Atualização da Diretriz Brasileira De Dislipidemias e Prevenção da Aterosclerose - 2017. SBC. 2017;109.

31. Nettleton JA, Follis JL, Ngwa JS, Smith CE, Ahmad S, Tanaka T, et al. Gene x dietary pattern interactions in obesity: Analysis of up to 68317 adults of European ancestry. Hum Mol Genet. 2015;24(16):4728-38.

32. Koochakpoor G, Daneshpour MS, Mirmiran P, Hosseini SA, Hosseini-Esfahani F, Sedaghatikhayat B, et al. The effect of interaction between Melanocortin-4 receptor polymorphism and dietary factors on the risk of metabolic syndrome. Nutr Metab [Internet]. 2016;13(1):1-9. Available from: http://dx.doi.org/10.1186/s12986-016-0092-z.

33. Mozaffarian D. Dietary and Policy Priorities for Cardiovascular Disease, Diabetes, and Obesity. Circulation. 2016;133(2):187-225.

34. Jiao J, Liu G, Shin HJ, Hu FB, Rimm EB, Rexrode KM, et al. Dietary fats and mortality among patients with type 2 diabetes: Analysis in two population based cohort studies. BMJ. 2019;366:8-11.

35. Afshin A, Micha R, Khatibzadeh S, Mozaffarian D. Consumption of nuts and legumes and risk of incident ischemic heart disease, stroke, and diabetes: A systematic review and meta-analysis. Am J 
Clin Nutr. 2014;100(1):278-88.

36. Martínez-González MA, Salas-Salvadó J, Estruch R, Corella D, Fitó M, Ros E. Benefits of the Mediterranean Diet: Insights From the PREDIMED Study. Prog Cardiovasc Dis [Internet]. 2015;58(1):50-60. Available from: http://dx.doi.org/10.1016/j.pcad.2015.04.003.

37. Jakulj F, Zernicke K, Bacon SL, Van Wielingen LE, Key BL, West SG, et al. A high-fat meal increases cardiovascular reactivity to psychological stress in healthy young adults. J Nutr. 2007;137(4):935-9.

38. O’Keefe JH, Bell DSH. Postprandial Hyperglycemia/Hyperlipidemia (Postprandial Dysmetabolism) Is a Cardiovascular Risk Factor. Am J Cardiol. 2007;100(5):899-904.

39. Wilson AS, Koller KR, Ramaboli MC, Nesengani LT, Ocvirk S, Chen C, et al. Diet and the Human Gut Microbiome: An International Review. Dig Dis Sci [Internet]. 2020;65(3):723-40. Available from: https://doi.org/10.1007/s10620-020-06112-w.

40. O’Keefe SJD. Diet, microorganisms and their metabolites, and colon cancer. Nat Rev Gastroenterol Hepatol [Internet]. 2016 Dec 16;13(12):691-706. Available from: http://www.nature.com/articles/nrgastro.2016.165.

41. O'Keefe SJD. The association between dietary fbre defciency and high-income lifestyle-associated diseases: Burkitt's hypothesis revisited. Lancet Gastroenterol Hepatol. 2019;4(12):984-96.

42. O'Keefe SJD. Plant-based foods and the microbiome in the preservation of health and prevention of disease. Am J Clin Nutr. 2019;110(2):265-6.

43. Kim Y, Je Y. Dietary fibre intake and mortality from cardiovascular disease and all cancers: A metaanalysis of prospective cohort studies. Arch Cardiovasc Dis [Internet]. 2016;109(1):39-54. Available from: http://dx.doi.org/10.1016/j.acvd.2015.09.005.

44. Park Y, Subar AF, Hollenbeck A, Schatzkin A. Dietary Fiber Intake and Mortality in the NIH-AARP Diet and Health Study. Arch Intern Med [Internet]. 2011 Jun 27;171(12):1-7. Available from: https://www.ncbi.nlm.nih.gov/pmc/articles/PMC3624763/pdf/nihms412728.pdf.

45. Benítez-Páez A, Gómez D, Pulgar EM, Kjølbæk L, Brahe LK, Astrup A, Larsen LH, et al. Impact of dietary fiber and fat on gut microbiota re-modeling and metabolic health. Trends Food Sci Technol. 2016;57:201-12.

46. Liu S, Willett WC, Manson JAE, Hu FB, Rosner B, Colditz G. Relation between changes in intakes of dietary fiber and grain products and changes in weight and development of obesity among middleaged women. Am J Clin Nutr. 2003;78(5):920-7.

47. Krzyszycha R, Szponar B. Body mass index (BMI) and dietary preferences of women living in rural areas. Rocz Państwowego Zakładu Hig. 2009;60(1):75-7.

48. Tucker LA. Fiber intake and insulin resistance in 6374 adults: The role of abdominal obesity. Nutrients. 2018;10(2).

49. Trigueros L, Peña S, Ugidos AV, Sayas-Barberá E, Pérez-Álvarez JA, Sendra E. Food Ingredients as Anti-Obesity Agents: A Review. Crit Rev Food Sci Nutr. 2013;53(9):929-42. 
50. Solah VA, Kerr DA, Hunt WJ, Johnson SK, Boushey CJ, Delp EJ, et al. Effect of fibre supplementation on body weight and composition, frequency of eating and dietary choice in overweight individuals. Nutrients. 2017;9(2):1-14.

51. Eastwood MA, Morris ER. Physical properties of dietary fiber that influence physiological function: A model for polymers along the gastrointestinal tract. Am J Clin Nutr. 1992;55(2):436-42.

52. Lafond DW, Greaves KA, Maki KC, Leidy HJ, Romsos DR. Effects of two dietary fibers as part of ready-to-eat cereal (RTEC) breakfasts on perceived appetite and gut hormones in overweight women. Nutrients. 2015;7(2):1245-66.

53. Lee I, Shi L, Webb DL, Hellström PM, Risérus U, Landberg R. Effects of whole-grain rye porridge with added inulin and wheat gluten on appetite, gut fermentation and postprandial glucose metabolism: A randomised, cross-over, breakfast study. Br J Nutr. 2016;116(12):2139-49.

54. Byrne CS, Chambers ES, Morrison DJ, Frost G. The role of short chain fatty acids in appetite regulation and energy homeostasis. Int J Obes [Internet]. 2015;39(9):1331-8. Available from: http://dx.doi.org/10.1038/ijo.2015.84.

55. Sánchez D, Miguel M, Aleixandre A. Dietary fiber, gut peptides, and adipocytokines. J Med Food. 2012;15(3):223-30.

56. Daniel L, Daniel S, Daniel TGilbert. M. W. Semantic and episodic memory. 2nd ed. New York: worth; 2011. 240-1 p.

57. National Institutes of Health; National Cancer Institute. Dietary Assessment Primer, 24-hour Dietary Recall (24HR) At a Glance. [Internet]. [cited 2020 Dec 3]. Available from: https://dietassessmentprimer.cancer.gov/.

58. DeBiasse MA, Bowen DJ, Quatromoni PA, Quinn E, Quintiliani LM. Feasibility and Acceptability of Dietary Intake Assessment Via 24-Hour Recall and Food Frequency Questionnaire among Women with Low Socioeconomic Status. J Acad Nutr Diet [Internet]. 2018;118(2):301-7. Available from: https://doi.org/10.1016/j.jand.2017.08.011.

59. IOM/ Food and Nutrition Board. Dietary Reference Intakes for Energy, Carbohydrate, Fiber, Fat, Fatty Acids, Cholesterol, Protein, and Amino Acids (Macronutrients). Natl Acad Press. 2002;5:107-264.

\section{Figures}




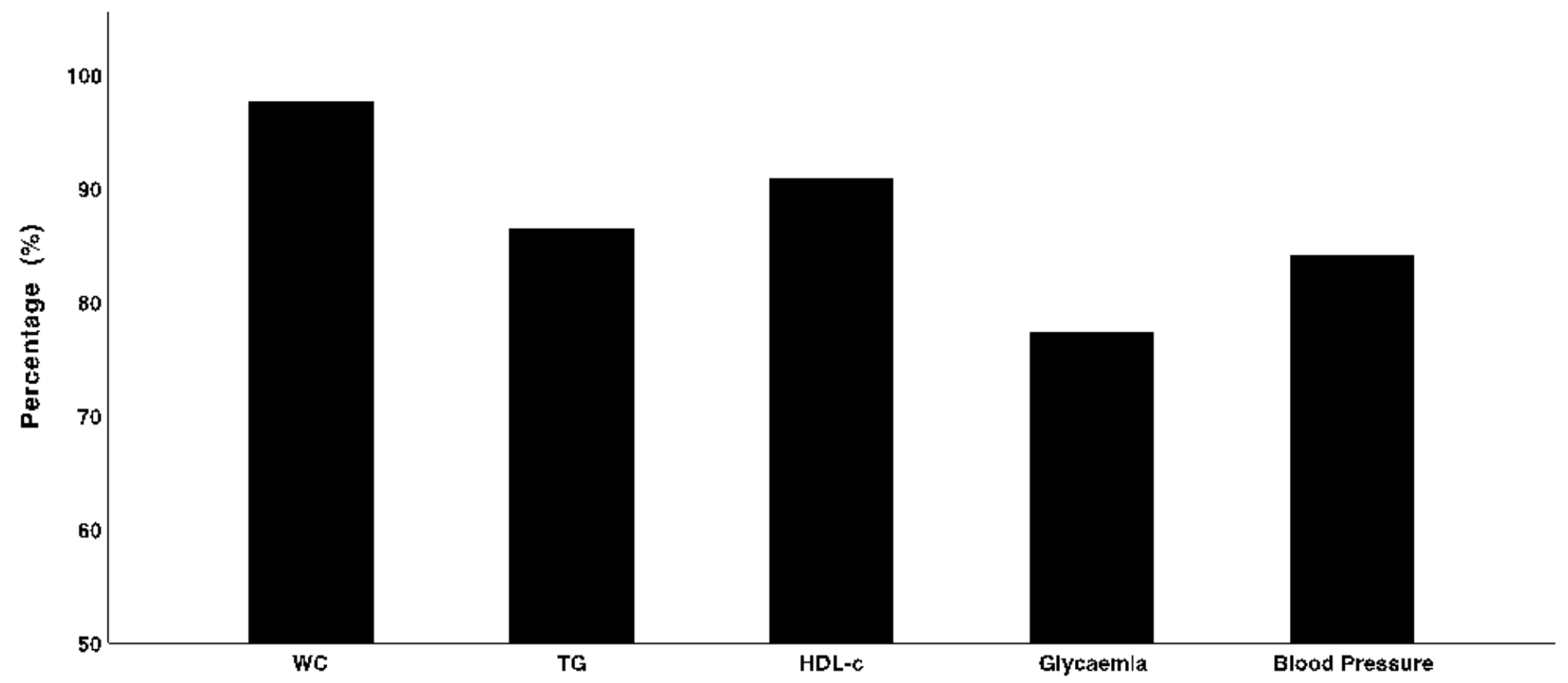

Figure 1

Prevalence of components of metabolic syndrome of women.

The values were expressed in percentual; WC: Waist Circumference $\geq 88 \mathrm{~cm} ;$ TG: Triglycerides $\geq 150$ $\mathrm{mg} / \mathrm{dl}$ or using medication for dyslipidemia; HDL-c: High Density Lipoproteins $<50 \mathrm{mg} / \mathrm{dL}$ o or using antilipemic; Glycaemia: Fasting venous glycaemia (FVG) $\geq 100 \mathrm{mg} / \mathrm{dl}$ or when using a hypoglycemic agent; Blood Pressure: systolic blood pressure (BP) $\geq 130$ and diastolic $\geq 85 \mathrm{~mm} / \mathrm{Hg}$ or when using antihypertensive drugs.

\section{Supplementary Files}

This is a list of supplementary files associated with this preprint. Click to download.

- STROBEchecklistv4combinedPlosMedicine.docx 